Mountain Lake and the Quill Lakes. With hunting pressure constantly increasing and if lead shot continues to be used, the mortality of Saskatchewan ducks due to lead poisoning can only increase. Monitoring this mortality factor is inexpensive and should be initiated on a large scale. Further studies may aid in preventing this cause of waterfowl mortality from becoming more serious.

'BELLROSE, F. C., Jr. 1964. Spent shot and lead poisoning. Waterfowl Tomorrow. United States Gov't. Printing Office, Washington, 479-485.
¿FLANEGAN, GENE. 1970. Lead poisoni problem solved? Ducks Unlimited Quarter 33(1), Chicago, 16 p.

"KIMBALL, W. H., and Z. A. MUNIR. 19 The corrosion of lead shot in a simulated wat fowl gizzard, Jour. Wildl. Mgmt. 35: 360-36

4TENNYSON, JON. 1971. The quest for a solutic Ducks Unlimited Quarterly 34(2), Chicago, p.

TTRAINER, D. O., and R. A. HUNT. 1965. Le poisoning of waterfowl in Wisconsin, Jour. Wil Mgmt. 29: 95-103.

\title{
THE COMMON DANDELION
}

\author{
by MARIE BARTON*
}

"Oh, dandelion, yellow as gold, What do you do all day?"

So read my prescribed grade-three reader in my early years. My preschool granddaughter with the imagination of a poet shouts, "Oh, look at those dandelions sitting on the clothesline!" I look and see a row of eye-catching goldfinches, eaters of dandelion seeds. They eat the flowers, too. A color food?

Children still make chains from the hollow, milky stalks of these flowers that bloom from May to September. They tell fortunes by blowing the cluster of white-plumed, beaked seeds from their platform until all have

\footnotetext{
*42 Echo Bay,

Winnipge, Manitoba

R2J 2 A 3
}

taken to the air. When the disks of $t$ composite gleam with its packe golden ray florets, the wild bee gath the pollen for bee bread and the nect for honey.

"If only they bloomed at Chri mas," sighs my retired, Swedish neig bor in the suburbs. He loves these ' $l$ starts' in his lawn less than do t children, the goldfinches and the be But he has lived enough years remember back to the homestead da Then he helped his grandfather cal water from the well to a carefu fenced, cultivated patch of the precious vegetables that he calls in mother tongue by the name of dev ; milk pots. (The French say dent-i. lion, meaning lion's tooth - 
-eference to the shiny leaves so sharply ncised and lobed, leaves that form a osette around the very short stem.) The mesh enclosure of the pioneer garten of dandelion herbs was sunk into he ground in order to keep out yophers.

\section{"The pioneers raised dandelions?"}

"Yes," he answers. "The flowers hade good wine. I make some even et. The leaves we cooked as we cook kale. I liked them in milk sauce or vith thick cream, sometimes butter.'

"And the roots?" I ask, for the 1973 Funk and Wagnall's New Encyclopedia ays that they "contain a substance ised as a laxative."

"Oh," he replies, "They made a cofee substitute. In those days we had ittle money for the real bean from the tore."

I have a friend, a back-to-nature puff, wife of a doctor, who digs the 2 o 12-inch long, fleshy, tap roots. She rims and cuts the washed pieces, then tries and bakes them in a slow oven on shallow pan. In lieu of a grinder, she crushes her processed product with a olling pin. "No caffeine," she says as he pours me a cupful of the brewed peverage. "It's good, I take it black."

In the spring this woman gathers ender young toothed leaves for salads and potherbs. Her Northern Cookbook from the Queen's Printer contains recipes. Some cookbooks recommend rdding sliced root to the greens. The herb is rich in vitamin $\mathrm{C}$. Though a conservationist, my friend harbors no scruples of conscience about gathering this wild source of food. "Like the starling, it is not on the list of endangered species." She laughs. "Since ancient times the plant has been gathered or cultivated for consumption.'

And like the starling and the English sparrow, the Common Dandelion, known by its Latin name as Taraxacum officinale, is an import from Europe. Dan McGowan of Banff is credited by Annora Brown in her book, Old Man's Garden, with the knowledge that it was the Hudson Bay Traders at Fort Churchill that used it "to balance a diet consisting too largely of meat."

\section{Olive Perry in Edible Wild Plants} gives the information that dandelion greens are obtainable in New York supermarkets for the gourmet taste. New Jersey market gardeners raise them in 2- to 4-acre lots. "Several horticultural varieties have been developed that form large leafy plants.'

Britannica includes dandelion greens as food for silkworms when silkworm farmers find that mulberry leaves are not to be had. A Russian species of dandelion is cultivated for its latex for the manufacture of rubber. Euell Gibbons in Stalking the Wild Asparagus has a chapter on the worth of the dandelion and how to use it.

Apparently as a survival measure this plant could be as useful to man as the reindeer to the Laplander greens, organic vitamins, honey, wine, medicine, 'coffee', bird food, silkworm forage, and source of rubber, not to mention its esthetic beauty and as a plaything for children. Whether one regards the lion's tooth that grows in temperate, Arctic and tropical regions, on roadsides, fields or tundra as friend or foe - it's all in your point of view.

Editor's Note: While the Common Dandelion is by far the best known of the dandelions, there are several other species, most of which occur in and near the mountains and were not introduced from abroad.

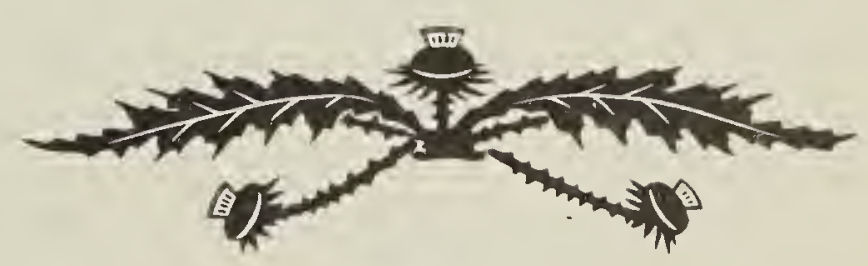

